\title{
Livelihood resilience and strategies of rural residents of earthquake-threatened areas in Sichuan Province, China
}

\author{
Wenfeng Zhou ${ }^{1} \cdot$ Shili Guo ${ }^{2} \cdot$ Xin Deng $^{3} \cdot$ Dingde Xu ${ }^{1,4}$
}

Received: 22 September 2020 / Accepted: 1 December 2020 / Published online: 2 January 2021

(c) The Author(s), under exclusive licence to Springer Nature B.V. part of Springer Nature 2021

\begin{abstract}
Natural disasters are increasing in frequency in China. Enhancing residents' livelihood resilience and adjusting their livelihood strategies have gradually become effective means of dealing with disaster risk. Therefore, it is of great significance to explore the livelihood strategies and livelihood resilience of rural residents in earthquake-stricken areas to help them cope with disaster risks. However, few studies have explored the correlation between residents' livelihood resilience and livelihood strategies from the perspective of residents' livelihood resilience. Based on a survey of 327 households in four districts and counties of Sichuan Province, China that were affected by the Wenchuan and Lushan earthquakes, we construct a framework for analyzing livelihood resilience and livelihood strategy selection. We comprehensively analyze the characteristics of livelihood resilience and livelihood strategy and explore their correlation using an ordinal multi-classification logistic regression model. The results show that: (1) Among 327 sample households, $90.21 \%$ were nonfarming, $3.67 \%$ were part-time households and $6.12 \%$ were farming households. Residents' livelihood resilience is mainly based on their disaster prevention and mitigation capacity. (2) As far as the correlation between livelihood resilience and livelihood strategies is concerned, the stronger the buffer capacity in livelihood resilience, the more rural residents tend to engage in non-farming activities to obtain income. When other conditions remain unchanged, the logarithmic probability of choosing an agricultural livelihood strategy decreases by 21.814 for each unit of buffer capacity. From the perspective of residents' livelihood resilience, this study deepens our understanding of the relationship between livelihood resilience and livelihood strategy in earthquake-stricken areas. It also provides useful information for the formulation of policies to improve residents' resilience in disaster-threatened areas.
\end{abstract}

Keywords Livelihood resilience · Livelihood strategy · Disaster prevention and mitigation · Earthquake-stricken areas · China

Dingde Xu

dingdexu@sicau.edu.cn

Extended author information available on the last page of the article 


\section{Introduction}

Since the twenty-first century, due to the influence of climate change and crustal movement, geological and natural disasters such as landslides, mudslides and earthquakes have occurred frequently (Peng et al. 2018; Xu et al. 2018a, b). Among them, earthquake, as the most serious disaster, has caused increasingly serious impact on the production and life of the local people (Peng et al. 2018; Tian et al. 2014). Sichuan Province is the most seriously earthquake-affected province in China since the twentieth century (Xu et al. 2020a, b, c). According to statistics, 167 earthquakes of magnitude 5 or above occurred in China from 2008 to 2019, resulting in 550,000 casualties and 1126.799 .37 million Yuan in direct economic losses. Among them, there were 19 earthquake disasters of magnitude 5 or above in Sichuan, accounting for $11.4 \%$ of the total, resulting in 530,000 casualties, accounting for $96.4 \%$ of the total, and direct economic losses of 931.0136 million Yuan, accounting for $82.6 \%$ of the total (CNSB 2019). Among them, the 5.12 Wenchuan earthquake was the most destructive earthquake since the founding of the People's Republic of China, and it was also the most deadly earthquake after the Tangshan earthquake, killing 69,268 people and injuring 446,062people, causing direct economic losses as high as 85,679,093 million Yuan (CNSB 2008). The April 20, 2013, Ya' an earthquake was a magnitude 7 or more earthquake, killing 196 people and injuring 13,217, with direct economic losses as high as 671,463 million Yuan (CNSB 2013). In addition to causing casualties and property and infrastructural losses, earthquake disasters also reduce agricultural productivity, thus hindering the economic development of earthquake-stricken areas (Xu et al. 2019a, b). As disaster risk seriously affects the sustainable development of rural residents in disaster areas (Bubeck et al. 2012; Huang et al. 2016; Lindell 2013; Lindell and Perry 2000), the construction of resilient disaster prevention systems in earthquake-stricken areas has gradually become a focus of interest in the field of disaster risk management. However, existing academic research on earthquake disaster risk management mostly concentrates on developed countries (Armas 2006; Becker et al. 2012; Doyle et al. 2018; Lindell et al. 2016), with relatively little focusing on earthquake-threatened areas of China. Therefore, such research is urgently needed (Lo and Cheung 2015; Xu et al. 2018a).

Facing the risk of earthquake disasters, timely adjustment of livelihood strategies can provide effective protection for individuals and families (Godschalk et al. 2003; Hoffmann and Muttarak, 2017; Lindell, 2013; Xu et al., 2018b). Livelihood strategy refers to the allocation of assets and selection of business activities by people to achieve their livelihood goals (Freduah et al. 2017; Guo et al. 2019a, b; Knutsson and Ostwald 2006; Xu et al. 2018a). Residents' livelihood strategies are not static and are constantly adjusted according to changes in policies, systems, the external environment, and personal livelihood capital (Xie et al. 2019). For example, when rural residents face risks or impacts from natural disasters, famine, or ecological degradation, they often change their livelihood strategies according to their own capital (Chen et al. 2014; Trinh et al. 2018). There has been much research on livelihood strategies and their drivers in the context of disasters (e.g., Iiyama et al. 2008; Israr et al. 2014; Kassie et al. 2017; Mentamo and Geda 2016; Mottaleb et al. 2018; Simtowe 2015). However, most studies focus on disasters such as extreme weather changes (Abid et al. 2016; Jezeer et al. 2019; Kuang et al. 2019), droughts (Alary et al. 2014), hurricanes (Schramski et al. 2013), and floods (Barr et al. 2000). Relatively few focuses on residents' livelihood strategy choices in the context of earthquake disasters, and such studies are urgently needed. 
Many scholars believe that in the face of an uncertain future, livelihood resilience may be the best way to enhance residents' livelihoods and promote their sustainable development (Adger et al. 2005; Folke 2006; Walker et al. 2004). Since Holling et al. (1973) put forward the theory of restoring force, academic research on this topic has gone through three different stages: (1) (late-1960s to the early-1970s) The focus of resilience research was "ecological resilience"; (2) (late-1970-1990s) scholars began to study "social-ecosystem resilience"; and (3) (2000-present) Adger (2000) introduced the concept of resilience into the field of social science, which began to focus on the resilience of human systems, social systems and communities, and gradually extended to the resilience of livelihoods (Davidson 2010). The core of sustainable livelihoods is livelihoods capital. Previous livelihoods studies have paid more attention to the stock and combination of farmers' livelihoods capital, but the accumulation and transformation of livelihoods capital cannot actively protect farmers from shocks, nor does it consider farmers' adaptation and adjustment behaviors under external shocks. Resilience thinking provides a new perspective for livelihood research and can help us understand how farmers maintain their livelihood level under the influence of adverse changes (Forster et al. 2014). Livelihood resilience refers to the ability of social systems to cope with and recover from disasters. Livelihood resilience focuses on how rural residents perceive changes in the social environment and how they modify their behaviors based on existing knowledge and social learning (Christensen et al. 2012; Cutter et al. 2008). Rural residents are the direct main body to deal with natural disaster risks and the basic unit of disaster prevention and mitigation management ( $\mathrm{Li}$ et al. 2014). Cultivating the livelihood resilience of rural residents in earthquake-stricken areas can help them cope with the impacts of disasters, maintain their vitality, and enhance their sustainable development ability. Therefore, the livelihood resilience of rural residents in earthquakestricken areas has become a focus of geography, disaster science, and sustainable development research. However, in existing research, there remain disputes regarding the composition and attributes of livelihood resilience. For example, Speranza et al. (2014) believe that livelihood resilience consists of three parts: buffer capacity, self-organization capacity, and the capacity for learning. Smith et al. (2018) decomposed resilience into absorptive capacity, adaptive capacity, and transformative capacity. Mekuyie et al. (2018) believe that the resilience of residents' livelihoods consists of six components: assets, adaptability, and social safety net, access to public services, stability, income, and food access. Different rural residents have different disaster prevention and mitigation capabilities. The secondary indicators of disaster prevention and mitigation capabilities in this study are whether to learn earthquake-related knowledge and whether to prepare emergency supplies, etc. It is based on residents' subjective consciousness to study their disaster prevention and mitigation capabilities. Jones et al. (2017) clearly pointed out that subjective resilience of farmers is related to the individual's ability to cope with risks and potential risk cognition of farmers. Measuring subjective resilience of farmers should emphasize its relationship with perceived adaptability, subjective well-being, and psychological adaptability. Nguyen and James (2013) used a more subjective approach to calculate the resilience of farmers' livelihoods at flood risk by assessing individual responses. Therefore, the ability of disaster prevention and mitigation of rural residents in earthquake-hit areas is crucial to their livelihood resilience (Cutter 2016; Despotaki et al. 2018; Speranza et al. 2014; Villagra et al. 2014). This study introduces the ability of disaster prevention and mitigation into the framework of livelihood resilience. However, there are few systematic studies on the resilience of residents' livelihoods in earthquake-threatened areas and such studies are urgently needed. 
Theoretically, residents' livelihood resilience is an important factor affecting their livelihood strategy choices. Farmers should obtain positive livelihood results to resist risks. High-quality and efficient livelihood capital is the guarantee for farmers to reduce their livelihood vulnerability and enhance their ability to resist risks. The status of farmers' livelihood capital determines their asset allocation mode, i.e., livelihood strategy. Previous livelihood studies have paid more attention to the stock and combination of farmers' livelihood capital. However, the accumulation and transformation of subsistence capital cannot actively protect farmers from shocks, nor does it consider the adaptation and adjustment behavior of farmers under external shocks. Compared with livelihood capital, the meaning of livelihood resilience includes not only its own resource endowment, but also the ability to sum up practical experience, create self-organization opportunities, cultivate learning, and adaptive behaviors, etc. Therefore, as a dynamic extension of livelihood capital, farmers' livelihood resilience can better reflect farmers' livelihood strategy choices under external shocks (Christensen et al. 2012; Cutter et al., 2008). However, according to existing research on the driving mechanisms of residents' livelihood strategies, there has been greater focus on the impacts of individual characteristics (such as age, gender, and education), family characteristics (such as family population and total family income), and cognitive characteristics (such as cognition of climate change) (Alam et al. 2016; Jin et al. 2015; Khanal et al. 2018; Li et al. 2017). Little research has explored the correlation between resilience and livelihood strategies (Liu et al. 2020; Thulstrup 2015). In the only research, scholars mostly focus on the impact of ecological resilience, community resilience, and disaster resilience on livelihood strategies. (e.g., DFID 1999; Holling et al. 1973). Few studies have systematically investigated the correlation between residents' livelihood resilience and livelihood strategy choices in earthquake-threatened areas from the perspective of livelihood resilience. Therefore, the relationship between household resilience and livelihoods adaptation strategies in the earthquake disaster threat areas needs to be further explored (Fang et al. 2018; Jiao et al. 2017).

This study is based on survey data obtained from 327 households in four counties of Sichuan Province affected by the Wenchuan and Lushan earthquakes. We measured residents' livelihood resilience from four aspects: buffer capacity, self-organization capacity, the capacity for learning, and disaster prevention and mitigation capacity. We construct an ordinal multi-classification logistic regression model to explore the correlation between livelihood resilience and livelihood adaptation strategies. This provides useful information for the formulation and implementation of policies related to disaster risk management. Compared with existing research, the contributions of this study are: (1) In the framework of livelihood resilience studied by predecessors, disaster prevention and mitigation capability is introduced into livelihood resilience framework according to the actual situation of the research area. (2) We explore its mechanism of action on residents' livelihood strategies from the perspective of their livelihood resilience, which is of great theoretical significance in understanding residents' livelihood strategies from the perspective of their ability. (3) We studied rural residents from typical areas of the Sichuan earthquake disaster. The results provide a reference for the construction of resilient disaster prevention systems in the vast earthquake-threatened areas of China. This study intends to solve the following two problems:

1. What are the characteristics of the livelihood resilience and livelihood strategies of rural residents of earthquake-stricken areas?

2. What is the correlation between residents' livelihood resilience and residents' livelihood strategies in earthquake-stricken areas? 


\section{Theoretical analysis and research hypotheses}

With the continuous acceleration of China's urbanization process, many rural laborers have immigrated to cities and the non-farming employment rate of rural residents has increased. Rural residents have changed from farming households to part-time households and even non-farming households. At the same time, many rural residents with high livelihood vulnerability and poor-risk resistance have been left behind in rural areas. High-quality and efficient livelihood resilience is the basis by which rural residents can reduce livelihood vulnerability and enhance risk resistance. Therefore, it is of great significance to study the livelihood resilience of rural residents of rural areas for livelihood strategies. This paper uses the reconstructed framework of residents' livelihood resilience to explore the correlation between residents' livelihood resilience and their livelihood strategies (Fig. 1).

Buffering capability is a measure of absorbing interference and changes while the system maintains its structure, characteristics, functions, and feedback unchanged (Carpenter et al. 2001; Holling et al. 2001). From the perspective of livelihood capital, buffer capacity is an important measure of livelihood resilience (Adger et al. 1999; Speranza et al. 2014). A strong buffer capacity is conducive to allowing families to use livelihood strategies to promote livelihood recovery and diversification (Marschke and Berkes 2006; Sina et al. 2019). On the one hand, the richer the arable land and fixed assets owned by residents, the more inclined they are to use large-scale mechanized production, thus improving farming efficiency and income. This can make rural residents more inclined to engage in agricultural activities (Yan 2011). On the other hand, with greater income and savings, families are more likely to invest in secondary and tertiary industries and develop into non-farming fields (Ahmed et al. 2018; Fang et al. 2014; Rahman et al. 2014). However, compared with the income from land resources, the income from financial capital is more objective to farmers, which is more conducive to the allocation of their own resources and the diversification of their livelihoods. Based on this, the study makes the following hypothesis:

H1 The stronger the buffer capacity of rural residents, the more farmers tend to non-agricultural livelihood strategies.

Self-organization ability emphasizes how people's self-management, institutional policies, and social connectivity shape resilience. The endogenous relevance and process of the system are the core of self-organization ability (Fuchs 2004; Obrist et al. 2010). Milestad et al. (2003) defined the self-organizing capacity of agricultural systems as the ability of rural residents or agricultural groups to establish flexible communication and mutual assistance networks and to integrate into the local social, economic, and institutional environment. Residents'

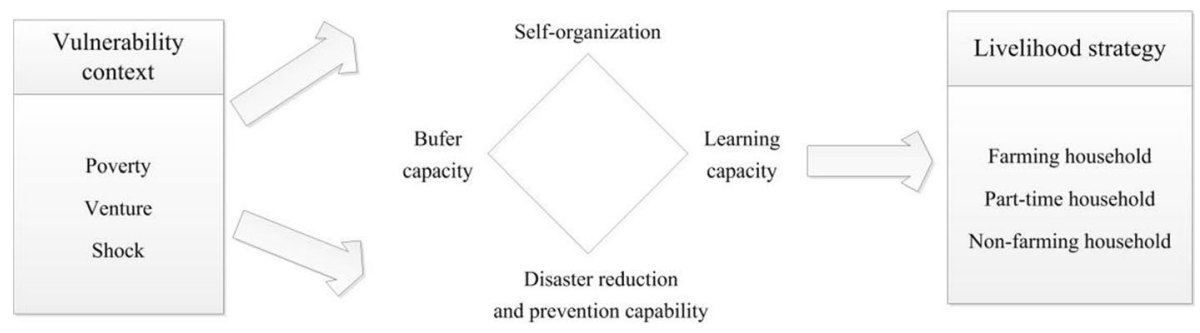

Fig. 1 Livelihood resilience and livelihood adaptation mechanism diagram 
self-organization ability affects their choice of livelihood activities. Compared with cities, rural areas pay more attention to human relations. Here, help from relatives and friends has a greater impact on residents' livelihood strategies (Xu et al. 2015). The improvement of selforganization ability can improve the availability of social resources. If rural residents are willing to spend more cost on social networks, then they are more likely to broaden their development space. Hence, rural residents are more likely to realize career diversification (Chen et al. 2014; De Jalon et al. 2018; Jones and Boyd 2011). Based on this, the study makes the following hypothesis:

H2 The stronger residents' self-organization ability, the more inclined rural residents are to adopt non-farming livelihood strategies.

The capacity for learning can be understood as the ability of individuals or organizations to create, acquire, disseminate knowledge, and memory, which is of great significance to their rapid response and recovery and reconstruction after being impacted (Speranza et al. 2014). The social-ecological system is dynamic, so rural residents need to continuously gain new knowledge and production skills, then adjust their livelihood strategies to suit (Hoffmann and Muttarak 2017). Generally speaking, improvement in the capacity for learning, especially in education level, makes the labor force more inclined to choose non-farming employment and more advanced occupations. Specifically, when the education level of the rural labor force gradually increases, they can gain higher income by choosing non-farming work. Rural residents with a higher education level are more inclined to engage in non-farming industries in cities than to return to rural areas to engage in agricultural labor (Alam et al. 2016; Mottaleb et al. 2018). Based on this, the study makes the following hypothesis:

H3 Stronger the capacity for learning makes rural residents more inclined to adopt nonfarming livelihood strategies.

Disaster prevention and mitigation capability refer to residents' capability to defend against natural disasters (Zhou et al. 2010). Wang et al. (2012) studied family disaster preparedness strategies from the perspective of vulnerability, pointing out that the family is the most basic disaster prevention cell. Hence, improving family disaster-response ability can strengthen their livelihood strategy. Generally speaking, rural residents with strong knowledge and resource ability related to disasters are more likely to choose non-farming livelihood strategies (Guo et al. 2018). At the same time, families with stronger awareness and ability to resist risks can send their surplus labor force out to work to gain more income to better resist risks. Based on this, the study makes the following hypothesis:

H4 Stronger ability to prevent and mitigate disasters makes rural residents more likely to adopt non-farming livelihood strategies.

\section{Data and methods}

\subsection{Introduction to research area}

Sichuan Province of China, the capital of Chengdu, is located in the southwest inland of China and is a famous earthquake disaster province in China and even in the world. 
Wenchuan earthquake and Ya'an earthquake are the most destructive and widespread earthquakes since the founding of the People's Republic of China. The Wenchuan earthquake caused 113,000 casualties and direct economic losses of 856.791 billion Yuan. The Ya' an earthquake affected 1.52 million people and affected an area of 12,500 square kilometers. Wenchuan earthquake and Ya' an earthquake have had a serious impact on the production and life of the local people.

\subsection{Data source}

All data used in this research were obtained from the Questionnaire on Residents' Livelihood and Disaster Risk Perception conducted by our research group in July 2019. Considering the differences in geographical environment and regional development, two districts and counties were selected from each of the areas hit by the Wenchuan and Lushan earthquakes. This resulted in a total of four districts and counties: Beichuan County, Pengzhou City, Lushan County, and Baoxing County. Questionnaires were answered during one-onone face-to-face interviews at the respondents' homes, each lasting 1-1.5 h. The questions related to the basic situation of the peasant household, their livelihood capital, and their livelihood strategy. To ensure the data were representative, we mainly adopted stratified equal-probability random sampling to determine the sample counties, villages, and residents. For the specific sampling process, please refer to Xu et al. (2019a, b), Zhuang et al. (2020). Through investigation, the survey data of 327 households in 16 villages in 8 villages and towns in 4 districts and counties were finally obtained. Figure 2 shows a map of the locations of the sampled counties, villages, and towns.

\subsection{Methods}

The objective of this study was to explore the correlation between residents' livelihood resilience and their livelihood strategy from the perspective of residents' livelihood resilience. To achieve this goal, some key variables were required, as follows.

\subsubsection{Type of household livelihood strategy}

For the measurement of livelihood strategies, based on Thulstrup et al. (2015), Liu et al. (2020), and other studies, the livelihood strategies of rural residents were divided into three types according to the proportion of household income obtained from agriculture: (1) farming household, (2) part-time household, and (3) non-farming household. Rural residents whose agricultural income accounted for $<50 \%$ of total household income were non-farming households. Those whose agricultural income accounted for 50-80\% of total household income were part-time households. Those whose agricultural income accounted for $>80 \%$ were farming households.

\subsubsection{Measurement of livelihood resilience}

For the measurement of livelihood resilience, we referred to Chen et al. (2014), Peng et al. (2019a), Speranza et al. (2014), Liu et al. (2020), Sina et al. (2019), and other studies and combined that information with the actual situation in the study area. In this study, livelihood resilience was divided into four dimensions: (1) buffer capacity, (2) self-organization capacity, (3) the capacity for learning, and (4) disaster prevention and mitigation capacity. 

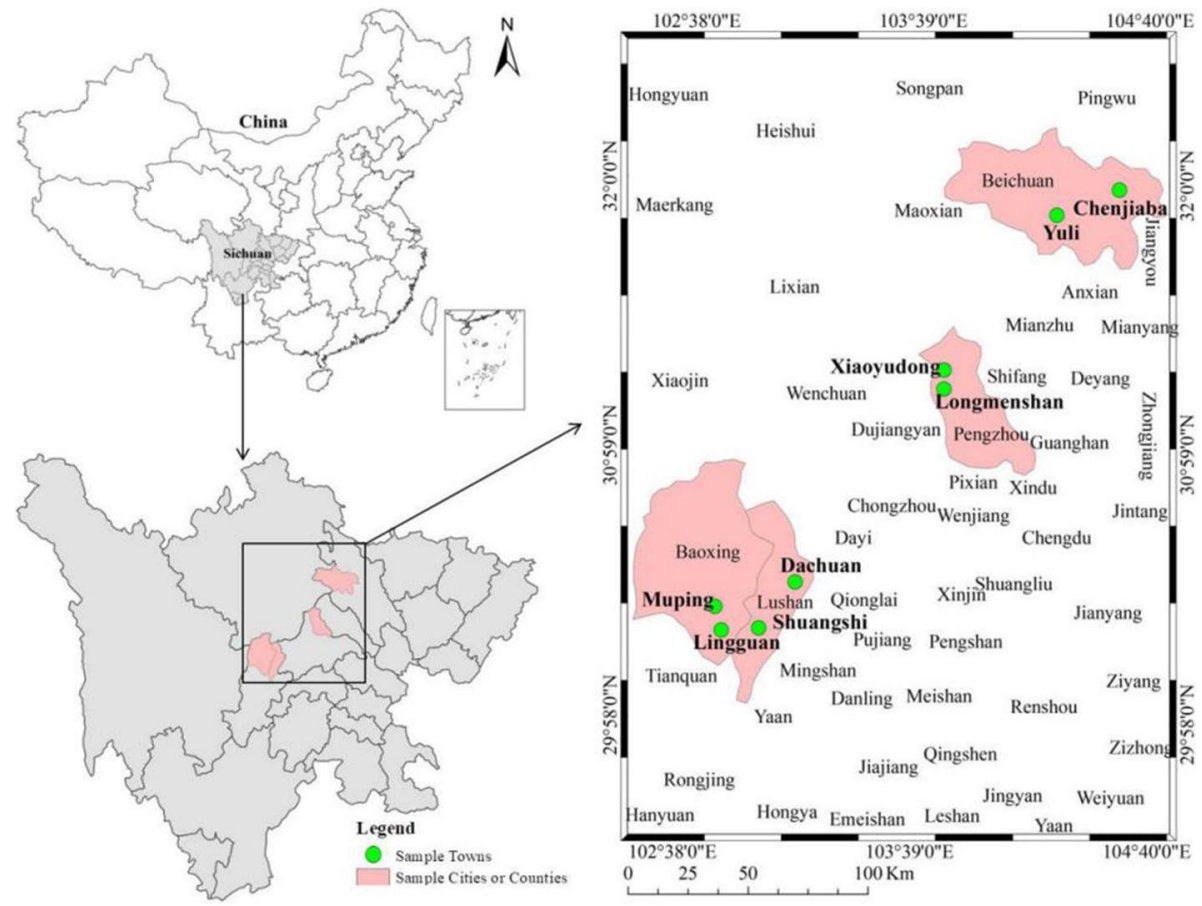

Fig. 2 Map of sample districts, counties, villages, and towns

Indicators were defined to measure these four categories (Table 1). Among them, buffer capacity depends on the amount and type of livelihood capital owned by the household. Based on the framework of sustainable livelihood analysis, this paper selects indicators that reflect the buffer capacity of farmers. Per capita arable land area and irrigation water source reflect the natural resources used by farmers for agricultural production and can represent the natural capital of farmers. Per capita annual income and deposits of households represent the financial capital of farmers. For farmers, their financial capital is the most effective and direct factor to resist interference and maintain their livelihood. The fixed assets of farmers can be realized and converted into financial capital when farmers encounter interference and risks. The number of labor force and dependency ratio in the family represents the family structure of farmers. Self-organization capacity refers to the establishment of flexible and changeable communication and mutual aid networks by residents, as well as their ability to integrate into the local social, economic, and institutional environment. The number of immediate family members and the presence or absence of village cadres in the family reflects the opportunities for farmers to obtain external help through their own social networks when encountering interference. The decision-making of social organizations or groups and community public affairs represents the ability of farmers to obtain development opportunities and integrate their own resource advantages. Self-organization ability was assessed based on the indicators of: the living conditions of rural residents in earthquake-stricken areas, the number of relatives and friends in their homes that were public officials, the social organizations or groups that rural residents participated in, whether they participated in community public affairs decision-making, and the distance 


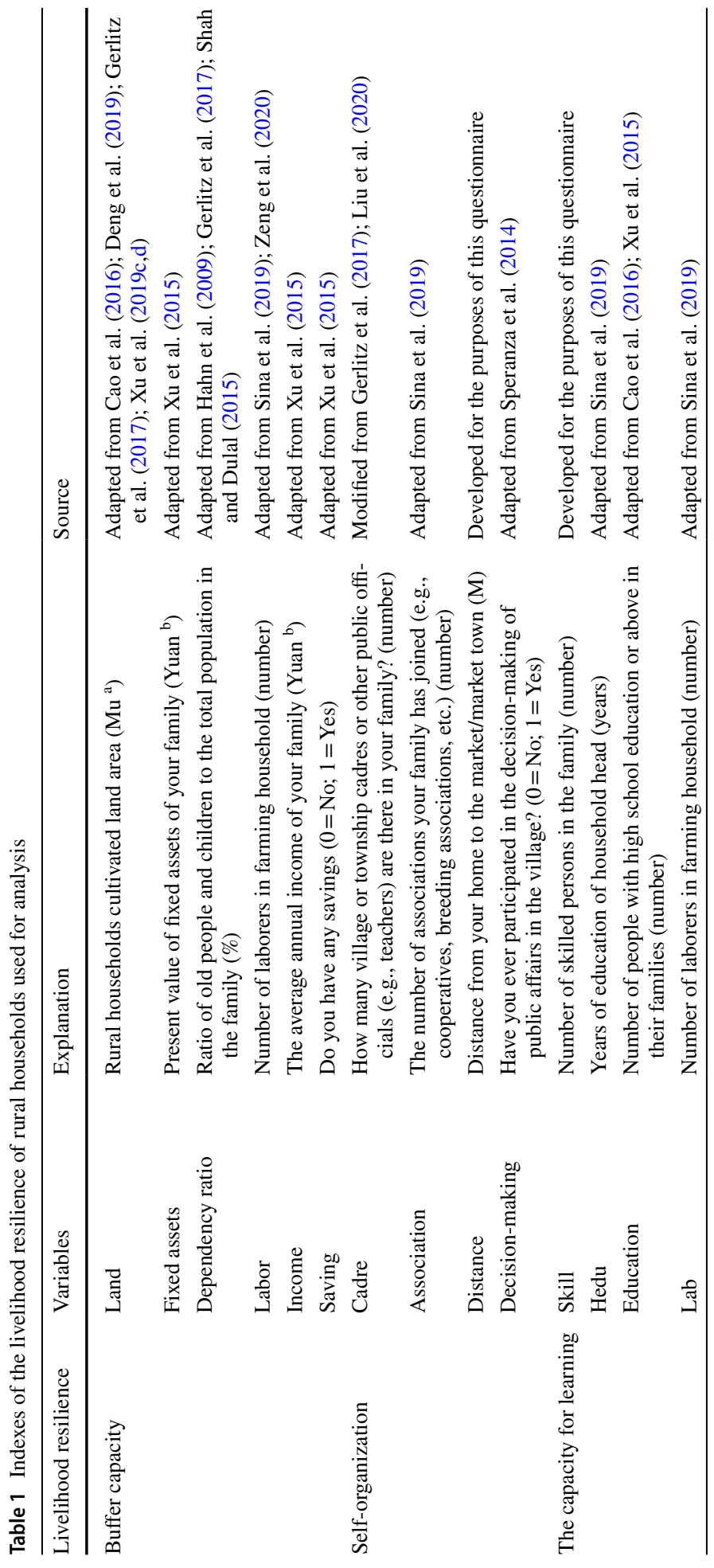




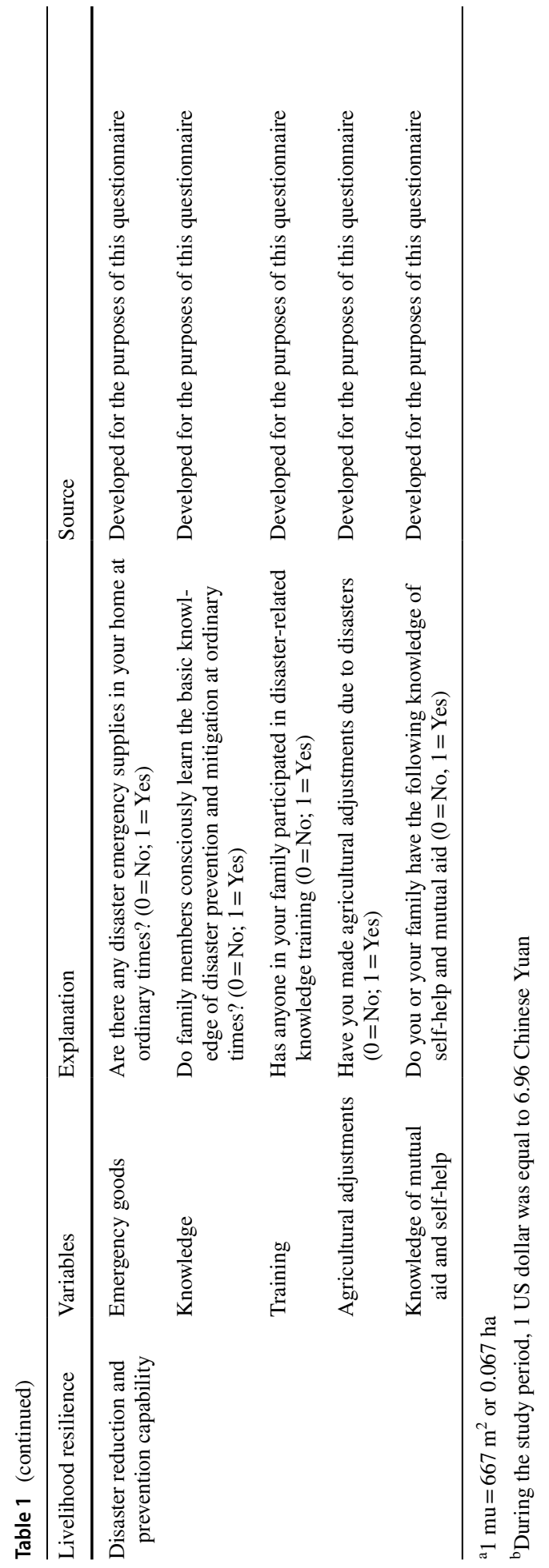


to the nearest town. The capacity for learning emphasizes the adaptive management of the system. Through knowledge, past experiences are applied to current practices and transformed into productivity, thus affecting the livelihood resilience of families. The higher the educational level of family members, the easier it is to grasp the development opportunities to adapt to social changes and lead families to choose more stable livelihood methods. The more skilled the number of people in the family, the easier it is to find high-quality jobs, thus ensuring the stability of their livelihood. Based on this, the study used the capacity for learning indicators of: the education level of the head of the household, the number of people with high school education or above, the number of people in the family with skills, and the number of people working abroad for long times. The core of disaster prevention and mitigation capability is residents' preparedness to avoid disasters. The indicators of this were whether rural residents had: emergency items prepared, learned disaster prevention knowledge, participated in disaster prevention training, knowledge of how to help themselves and others, and made disaster-related agricultural adjustments.

\subsubsection{Measurement model}

The dependent variable was the type of farmer livelihood adaptation strategy, which is an ordinal and multi-classified variable. The independent variables were residents' livelihood resilience, continuous variables, and classified variables. Considering the distribution characteristics of the variables, this study attempted to construct an ordered multi-classification logistic regression econometric model to explore the correlation between residents' livelihood resilience and their livelihood adaptation strategies. The simple expression of the model is as follows:

$$
Y=\alpha_{0}+\alpha_{1} \times \text { Livelihood resilience }_{i}+\varepsilon_{i}
$$

In the formula, $Y$ refers to the residents' livelihood strategy; Livelihood resilience is the core independent variable of the model, which indicates the resilience of residents' livelihood capital. $\alpha_{0}, \alpha_{1}, \beta_{0}, \beta_{1}$, respectively, represent the parameters to be estimated of the model, and $\varepsilon_{i}$ and $\sigma_{i}$ are the residual terms of the model. The estimation of the whole research model is realized by SPSS 24 .

\section{Results}

\subsection{Descriptive statistics of the variables}

\subsubsection{Characteristics of residents' livelihood strategies}

Figure 3 shows a distribution graph of residents' livelihood strategies. It shows that nonfarming households accounted for the vast majority of rural residents of earthquakethreatened areas, while part-time and farming households were fewer. Specifically, 295 of 327 sampled rural residents were non-farming households, accounting for $90.21 \%$ of the total sample. There were also 12 part-time households $(3.67 \%)$ and 20 farming households $(6.12 \%)$. 


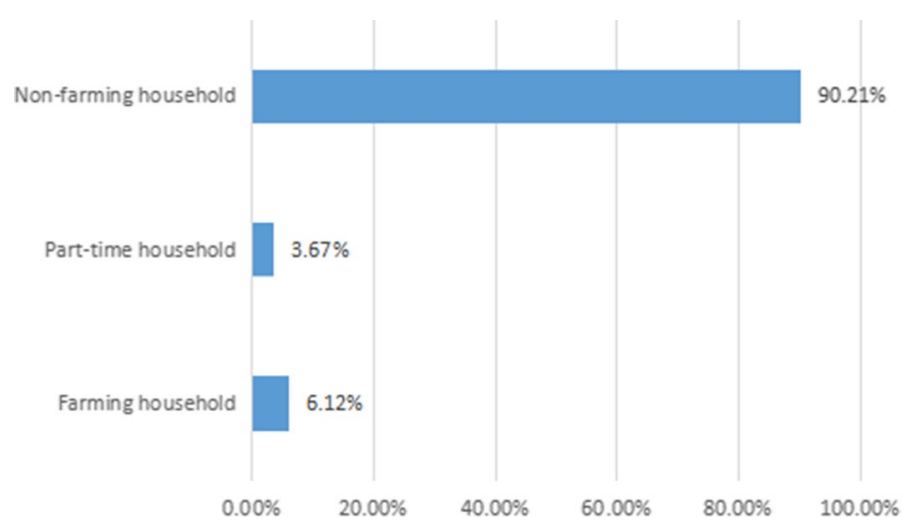

Fig. 3 Distributions of farmer types

\subsubsection{Livelihood resilience characteristics}

The purpose of this study was to explore the correlation between livelihood resilience and livelihood strategies. Entropy method is an objective weighting mathematical method used to judge the degree of index dispersion. The greater the dispersion degree of entropy value, the greater the influence of this index on comprehensive evaluation. Compared with qualitative analysis methods such as analytic hierarchy process (relatively subjective), entropy method has more objective results. The entropy method is used as a quantitative evaluation method to obtain the weight of each dimension index and the comprehensive index of each dimension that characterize the resilience of farmers' livelihood. The principle and detailed calculation steps of entropy method are detailed in Peng et al. (2019b) and Xu et al (2019a).

Table 2 shows the definitions and descriptive statistics of the independent variables used in the model. As shown in Table 2, the livelihood resilience of rural residents in the earthquake disaster threat areas is mainly based on disaster prevention and mitigation ability, with the highest comprehensive index of 0.082 , the comprehensive index of buffer ability and self-organization ability of 0.03 , and the lowest comprehensive index of the capacity for learning of 0.024 .

Table 2 Definitions and descriptive statistics of the variables used in the model

\begin{tabular}{llll}
\hline Variable & Measure & Mean & SD \\
\hline Buffer capacity & Scores for buffer capacity of rural households (0-1) & 0.053 & 0.030 \\
Self-organization & Scores for self-organization of rural households (0-1) & 0.035 & 0.030 \\
The capacity for learning & Scores for the capacity for learning of rural households (0-1) & 0.033 & 0.024 \\
$\begin{array}{l}\text { Disaster reduction and } \\
\text { prevention capability }\end{array}$ & $\begin{array}{c}\text { Scores for disaster reduction and prevention capability of rural } \\
\text { households (0-1) }\end{array}$ & 0.120 & 0.082 \\
Type of peasant household & Scores for type of peasant household of rural households (0-1) & 0.159 & 0.507 \\
\hline
\end{tabular}




\subsection{Econometric model results}

Table 3 shows the results of the regression of the four dimensions of residents' livelihood resilience and their livelihood strategy choices. The test statistics indicate that the model as a whole is significant at the level of 0.05 and, at the same time, the independent variable can explain $4.44 \%$ of the variation in the dependent variable.

As shown in Table 3, the buffering capacity of rural residents is negatively correlated with their livelihood strategies. Specifically, when the other conditions are the same, the logarithmic probability of choosing an agricultural livelihood strategy decreases by 21.814 for each additional unit of residents' buffer capacity. The correlation between household self-organization ability, the capacity for learning, disaster prevention and mitigation ability, and their livelihood strategy choice is not significant Fig 4.

\section{Discussion}

Based on survey data of rural residents in the worst-hit areas of the Wenchuan and Lushan earthquakes, this study empirically analyzed the correlations between residents' livelihood resilience factors and their livelihood strategies. There were some differences between our results and those of similar studies, as follows.

Consistent with research hypothesis H1, Su et al. (2009), Yan et al. (2011) and other research results, this study found that rural residents with a stronger buffer capacity are more inclined to obtain a higher income through non-farming activities.

Inconsistent to research hypothesis H2, Binder et al. (2015), Bukvic et al. (2017), Liu et al. (2020), and other research results, they found that the stronger the residents' selforganizing ability, the more inclined they were to adopting non-farming livelihood strategies. However, we found no significant correlation between residents' self-organizing ability and their livelihood strategies. The possible reason is that the study area is a region where earthquakes and poverty are intertwined. The rural residents who stay in these areas are relatively vulnerable, and their social networks are limited. The possible reason is that the proportion of relatives and friends in government was small, and the participation of rural residents in social and economic organizations was relatively low. Of the 327 sampled residents, only $42.3 \%$ had relatives and friends working in the government, while $15.3 \%$ participated in social and economic organizations.

Table 3 Correlation between livelihood resilience and residents' livelihood strategy

\begin{tabular}{lcccc}
\hline Variable & Regression coefficient & $\begin{array}{l}\text { Robust standard } \\
\text { error }\end{array}$ & $T$ value & $P$ value \\
\hline Buffer capacity & -21.814 & 7.444 & -2.93 & $0.003^{* *}$ \\
Self-organization & -2.480 & 6.619 & -0.37 & 0.708 \\
The capacity for learning & -5.582 & 13.154 & -0.42 & 0.671 \\
$\begin{array}{l}\text { Disaster reduction and preven- } \\
\quad \text { tion capability }\end{array}$ & 1.400 & 2.513 & 0.56 & 0.579 \\
Prob>chi & & & & \\
$R^{2}$ & 0.0287 & & & \\
\hline
\end{tabular}

$* * * p<0.01, * * p<0.05, * p<0.1$ 


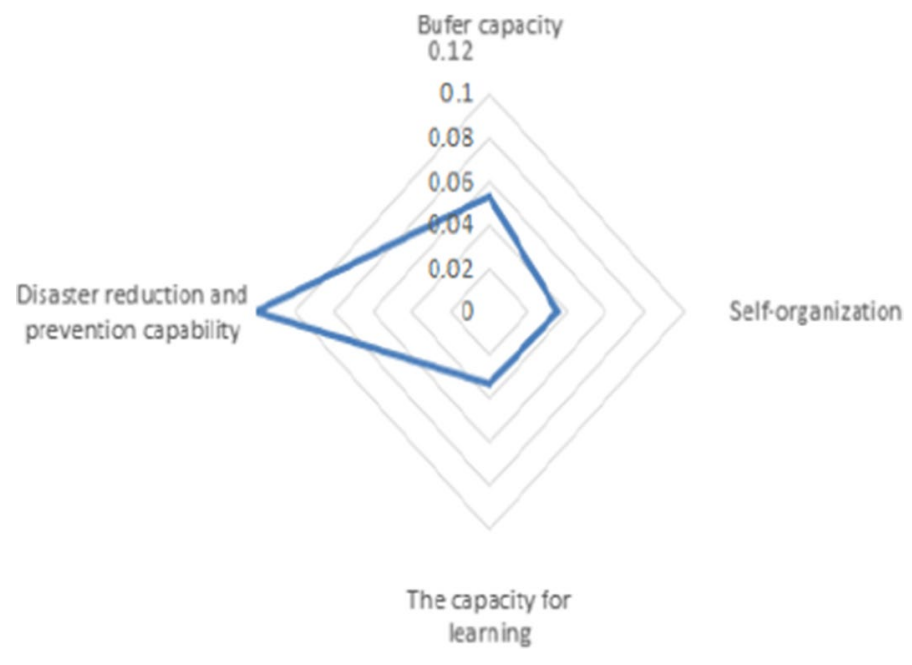

Fig. 4 Livelihood resilience radar map

Inconsistent to research hypothesis H3 and Hoffmann and Muttarak (2017), Liu et al. (2015, 2020), Thomas et al. (2018), Whitehead et al. (2001), Xie et al. (2008), and other research results, they found that the stronger the residents' the capacity for learning, the more inclined the rural residents to adopt non-farming livelihood strategies. However, this study found that there was no significant correlation between residents' the capacity for learning and their livelihood strategy choices. The possible reasons are: The study area is a region where earthquakes and poverty are intertwined. The education level of the labor force was generally low, being mainly the primary and secondary levels. Few rural residents had more than a secondary education and most lacked professional skills, which may limit the influence of the capacity for learning on their livelihood strategy.

Inconsistent with hypothesis H4 and Guo et al. (2018), we found no significant correlation between residents' disaster prevention and mitigation ability and their livelihood strategies. The possible reason is that the overall disaster prevention ability of rural residents in earthquake-stricken areas is relatively weak. On the one hand, rural residents may have "survivor bias", causing them to underestimate the severity of disaster risks (Xu et al. $2020 \mathrm{a}, \mathrm{c}$ ), so they do not prepare disaster avoidance materials or adjust their livelihood strategy. On the other hand, residents' financial capital levels were relatively low and they had no surplus funds for disaster preparation. These rural residents are reluctant to bear the risks brought about by adjusting their livelihood strategy. Therefore, in general, there is no correlation between residents' disaster prevention and mitigation ability and their livelihood strategy.

In addition, there are still some deficiencies in this study. For example, the livelihood of farmers is a dynamic development process. This study only evaluates the resilience level of farmers' livelihood at a time node, and the time evolution process of farmers' livelihood resilience needs further research. At the same time, this paper only discusses the relationship between residents' livelihood resilience and livelihood strategies in the worst-hit areas of Wenchuan earthquake and Lushan earthquake. Whether the research results are applicable to other earthquake-hit areas needs further discussion. In the future, it is necessary to expand the scope of research objects and explore the relationship between livelihood 
resilience and livelihood strategies of residents in earthquake-stricken areas of different degrees.

\section{Conclusions}

Based on the analysis, this study draws two main conclusions:

(1) Rural residents' livelihood strategies are divided into non-agricultural, part-time and pure agricultural types, and non-agricultural is the main livelihood strategy adopted by rural residents in earthquake disaster threat areas. Of 327 sample households, $90.21 \%$ are non-agricultural residents, $3.67 \%$ are part-time residents, and $6.12 \%$ are pure agricultural residents. The resilience of rural residents' livelihood can be divided into buffer capacity, self-organization capacity, learning capacity, and disaster prevention and mitigation capacity, and the resilience of rural residents' livelihood is mainly based on disaster prevention and mitigation capacity.

(2) As far as the correlation between livelihood resilience and livelihood strategies is concerned, the stronger the buffer capacity in livelihood resilience, the more rural residents tend to engage in non-agricultural production activities to obtain income. When other conditions remain unchanged, the logarithmic probability of choosing agricultural livelihood strategy decreases by 21.814 for each additional unit of farmers' buffer capacity.

The theoretical significance of this study is that in the framework of previous graduate students' resilience calculation, according to the actual situation of the study area, introducing disaster prevention and mitigation capabilities into the livelihoods resilience framework, from the perspective of residents' livelihood resilience, it is of great theoretical significance to understand residents' livelihood strategies from the perspective of residents' ability, and the research results can provide reference basis for the construction of resilient disaster prevention system in earthquake-stricken areas.

In addition to their theoretical significance, the results of this study also have important policy implications. Under the background of novel coronavirus pneumonia, rural residents in rural areas face unprecedented difficulties in their life and employment. Therefore, the government should take corresponding measures to improve residents' livelihood resilience so as to enhance their ability to resist risks and ensure the sustainable development of their livelihood. (1)This study found that the ability to resist and reduce disasters is the main component of residents' livelihood resilience in earthquake-hit areas. Therefore, the government should organize farmers to learn about earthquakes and learn relevant disaster avoidance preparations and emergency measures, so as to actively guide farmers to establish correct cognitive concepts of earthquake disasters. (2) We found that the total income of families following an agricultural livelihood strategy was far less than that of families following a non-farming strategy. Therefore, the government should provide financial support that encourages rural residents to change their livelihood strategies. This would not only protect the fragile ecological environment to a certain extent but also maintain the diversification of residents' planning strategies and better resist external risks. (3)This study found that the stronger the buffer capacity of residents, the more rural residents undertook non-farming production activities. Therefore, the government should expand residents' capital stock through different channels to enhance their buffer capacity 
and enable them to better resist external risks. For example, employment training and guidance in helping rural residents find external work could increase their income.

Acknowledgements We gratefully acknowledge financial support from National Natural Science Foundation of China (No. 41801221), the Dual Support Plan of Sichuan Agricultural University, and Special program for training outstanding young talents of the Dual Support Plan of Sichuan Agricultural University. The authors also extend great gratitude to the anonymous reviewers and editors for their helpful review and critical comments.

Data availability The use of data in this study is entirely ethical and the author can provide it separately if necessary.

\section{Compliance with ethical standards}

Conflict of interest The authors declare that they have no conflict of interest.

\section{References}

Abid M, Schneider UA, Scheffran J (2016) Adaptation to climate change and its impacts on food productivity and crop income: Perspectives of farmers in rural Pakistan. J Rural Stud 47:254-266. https://doi. org/10.1016/j.jrurstud.2016.08.005

Adger WN, Hughes TP, Folke C, Carpenter SR, Rockström J (2005) Social-ecological resilience to coastal disasters. Science 309(5737):1036-1039. https://doi.org/10.1126/science.1112122

Adger WN (2000) Social and ecological resilience: are they related? Prog Hum Geogr 24(3):347-364. https ://doi.org/10.1191/030913200701540465

Adger WN, Kelly PM (1999) Social vulnerability to climate change and the architecture of entitlements. Mitig Adapt Strat Glob Change 4(3-4):253-266. https://doi.org/10.1023/a:1009601904210

Ahmed MT, Bhandari H, Gordoncillo PU, Quicoy CB, Carnaje GP (2018) Factors affecting extent of rural livelihood diversification in selected areas of Bangladesh. SAARC J Agric 16(1):7-21. https://doi. org/10.3329/sja.v16i1.37419

Alam GM, Alam K, Mushtaq S (2016) Influence of institutional access and social capital on adaptation decision: empirical evidence from hazard-prone rural households in Bangladesh. Ecol Econ 130:243251. https://doi.org/10.1016/j.ecolecon.2016.07.012

Alary V, Messad S, Aboul-Naga A, Osman MA, Daoud I, Bonnet P, Tourrand JF (2014) Livelihood strategies and the role of livestock in the processes of adaptation to drought in the coastal zone of Western Desert (Egypt). Agric Syst 128:44-54. https://doi.org/10.1016/j.agsy.2014.03.008

Armas I (2006) Earthquake risk perception in Bucharest. Romania Risk Anal 26(5):1223-1234. https://doi. org/10.1111/j.1539-6924.2006.00810.x

Barr, J. (2000). Investigation of livelihood strategies and resource use patterns in floodplain production systems in Bangladesh. DFID-NRSP Project, 6756.

Becker JS, Paton D, Johnston DM, Ronan KR (2012) A model of household preparedness for earthquakes: how individuals make meaning of earthquake information and how this influences preparedness. Nat Hazards 64(1):107-137. https://doi.org/10.1007/s11069-012-0238-x

Binder SB, Baker CK, Barile JP (2015) Rebuild or relocate? Resilience and post disaster decision-making after hurricane sandy. Am J Commun Psychol 56(1-2):180-196. https://doi.org/10.1007/s1046 4-015-9727-x

Bubeck P, Botzen WJW, Aerts JCJH (2012) A review of risk perceptions and other factors that influence flood mitigation behavior. Risk Anal 32(9):1481-1495. https://doi.org/10.111 1/j.1539-6924.2011.01783.x

Bukvic A, Owen G (2017) Attitudes towards relocation following Hurricane Sandy: should we stay or should we go? Disasters 41(1):101-123. https://doi.org/10.1016/j.ijdrr.2015.06.008

Cao M, Xu D, Xie F, Liu E, Liu S (2016) The influence factors analysis of households' poverty vulnerability in southwest ethnic areas of China based on the hierarchical linear model: a case study of Liangshan Yi autonomous prefecture. Appl Geogr 66:144-152. https://doi.org/10.1016/j.apgeog.2015.11.016

Carpenter S, Walker B, Anderies JM, Abel N (2001) From metaphor to measurement: resilience of what to what? Ecosystems 4(8):765-781. https://doi.org/10.2307/3659056 
Chen H, Wang J, Huang J (2014) Policy support, social capital, and farmers' adaptation to drought in China. Global Environ Change 24:193-202. https://doi.org/10.1016/j.gloenvcha.2013.11.010

Christensen L, Krogman N (2012) Social thresholds and their translation into social-ecological management practices. Ecol Soc 17(1):5. https://doi.org/10.5751/ES-04499-170105

CNSB (China National Statistical Bureau) (2019) China yearbook of household survey in 2019. China Statistical Press, Beijing ((in Chinese))

CNSB (China National Statistical Bureau) (2013) China yearbook of household survey in 2013. China Statistical Press, Beijing ((in Chinese))

CNSB (China National Statistical Bureau) (2008) China yearbook of household survey in 2008. China Statistical Press, Beijing ((in Chinese))

Cutter SL, Ash KD, Emrich CT (2016) Urban-rural differences in disaster resilience. Annals American As Geogr 106(6):1236-1252. https://doi.org/10.1080/24694452.2016.1194740

Cutter SL, Barnes L, Berry M et al (2008) A place-based model for understanding community resilience to natural disasters. Global Environ Change 18(4):598-606. https://doi.org/10.1016/j.gloen vcha.2008.07.013

Davidson DJ (2010) The applicability of the concept of resilience to social systems: some sources of optimism and nagging doubts. Soc Nat Resour 23(12):1135-1149. https://doi.org/10.1080/08941 921003652940

Deng X, Xu D, Zeng M, Qi Y (2019) Does Internet use help reduce rural cropland abandonment? Evidence from China Land Use Policy 89:104243. https://doi.org/10.1016/j.landusepol.2019.104243

Despotaki V, Sousa L, Burton CG (2018) Using resilience indicators in the prediction of earthquake recovery. Earthquake Spectra 34(1):265-282. https://doi.org/10.1193/071316EQS107M

De Jalón SG, Iglesias A, Neumann MB (2018) Responses of sub-Saharan smallholders to climate change: strategies and drivers of adaptation. Environ Sci Policy 90:38-45. https://doi.org/10.1016/j.envsc i.2018.09.013

DFID UK (1999) Sustainable livelihoods guidance sheets. DFID, London, p 445

Doyle EEH, McClure J, Potter SH, Becker JS, Johnston DM, Lindell MK et al (2018) Motivations to prepare after the 2013 Cook Strait Earthquake, N.Z. Int J Disaster Risk Reduct 31:637-649. https ://doi.org/10.1016/j.ijdrr.2018.07.008

Fang YP, Zhu FB, Qiu XP, Zhao S (2018) Effects of natural disasters on livelihood resilience of rural residents in Sichuan. Habitat Int 76:19-28. https://doi.org/10.1016/j.habitatint.2018.05.004

Folke C (2006) Resilience: the emergence of a perspective for social- ecological systems analyses. Global Environ Change 16(3):253-267. https://doi.org/10.1016/j.gloenvcha.2006.04.002

Fang YP, Fan J, Shen MY, Song MQ (2014) Sensitivity of livelihood strategy to livelihood capital in mountain areas: empirical analysis based on different settlements in the upper reaches of the Minjiang River, China. Ecol Ind 38:225-235. https://doi.org/10.1016/j.ecolind.2013.11.007

Frazier TG, Thompson CM, Dezzani RJ, Butsick D (2013) Spatial and temporal quantifcation of resilience at the community scale. Appl Geogr 42:95-107. https://doi.org/10.1016/j.apgeo g.2013.05.004

Freduah G, Fidelman P, Smith TF (2017) The impacts of environmental and socio-economic stressors on small scale fisheries and livelihoods of fishers in Ghana. Appl Geogr 89:1-11. https://doi. org/10.1016/j.apgeog.2017.09.009

Forster J, Lake IR, Watkinson AR (2014) Marine dependent livelihoods and resilience to environmental change: a case study of Anguilla. Marine Policy 45(3):204-212

Fuchs C (2004) The antagonistic self-organization of modern society. Stud Political Econ 73(1):183209. https://doi.org/10.1080/19187033.2004.11675157

Gerlitz JY, Macchi M, Brooks N, Pandey R, Banerjee S, Jha SK (2017) The multidimensional livelihood vulnerability index - an instrument to measure livelihood vulnerability to change in the Hindu Kush Himalayas. Clim Dev 9(2):124-140

Godschalk DR (2003) Urban hazard mitigation: creating resilient cities. Nat Hazards Rev 43:136-143. https://doi.org/10.1061/(ASCE)1527-6988,4,3(136)

Guo SL, Li CJ, Wei YL, Zhou K, Liu SQ, Li QY (2019a) Impact of land expropriation on farmers' livelihoods in the mountainous and hilly regions of Sichuan. China J Mt Sci 16(11):2484-2501. https ://doi.org/10.1007/s11629-018-5017-Z

Guo S, Lin L, Liu S, Wei Y, Xu D, Li Q, Su S (2019b) Interactions between sustainable livelihood of rural household and agricultural land transfer in the mountainous and hilly regions of Sichuan. China Sustain Dev 27(4):725-742. https://doi.org/10.1002/sd.1937

Guo YL (2018) Research on farmers' perception of heavy rainfall disaster and livelihood strategies in mountainous areas. Fujian Agriculture and Forestry University, Fujian ((in Chinese)) 
Hahn MB, Riederer AM, Foster SO (2009) The livelihood vulnerability tndex: a pragmatic approach to assessing risks from climate variability and change-A case study in Mozambique. Glob Environ Change 19(1):74-88

Hoffmann R, Muttarak R (2017) Learn from the past, prepare for the future: impacts of education and experience on disaster preparedness in the Philippines and Thailand. World Dev 96:32-51. https:// doi.org/10.1016/j.worlddev.2017.02.016

Holling CS (1973) Resilience and stability of ecological systems. Annu Rev Ecol Syst 4(1):1-23

Holling CS (2001) Understanding the complexity of economic, ecological, and social systems. Ecosystems 4(5):390-405. https://doi.org/10.1007/s10021-001-0101-5

Huang SK, Lindell MK, Prater CS (2016) Who leaves and who stays? A review and statistical meta-analysis of hurricane evacuation studies. Environ Behav 48(8):991-1029. https://doi. org/10.1177/0013916515578485

Israr M, Khan H, Jan D, Ahmad N (2014) Livelihood diversification: a strategy for rural income enhancement. J Financ Econ 2(5):194-198. https://doi.org/10.12691/jfe-2-5-10

Iiyama M, Kariuki P, Kristjanson P, Kaitibie S, Maitima J (2008) Livelihood diversification strategies, incomes and soil management strategies: a case study from Kerio Valley, Kenya. J Int Dev: J Dev Stud As 20(3):380-397. https://doi.org/10.1002/jid.1419

Jezeer RE, Verweij PA, Boot RG, Junginger M, Santos MJ (2019) Influence of livelihood assets, experienced shocks and perceived risks on smallholder coffee farming practices in Peru. J Environ Manage 242:496-506. https://doi.org/10.1016/j.jenvman.2019.04.101

Jiao X, Pouliot M, Walelign SZ (2017) Livelihood strategies and dynamics in rural Cambodia. World Dev 97:266-278. https://doi.org/10.1016/j.worlddev.2017.04.019

Jin JJ, Gao YW, Wang XM, Nam PK (2015) Farmers' risk preferences and their climate change adaptation strategies in the Yongqiao District. China Land Use Policy 47:365-372. https://doi. org/10.1016/j.landusepol.2015.04.028

Jones L, Boyd E (2011) Exploring social barriers to adaptation: insights from Western Nepal. Global Environ Change 21(4):1262-1274. https://doi.org/10.1016/j.gloenvcha.2011.06.002

Jones L, Tanner T (2017) "Subjective resilience": using perceptions to quantify household resilience to climate extremes and disasters. Reg Environ Change 17(1):229-243. https://doi.org/10.1007/ s10113-016-0995-2

Kassie GW (2017) The Nexus between livelihood diversification and farmland management strategies in rural Ethiopia. Cogent Econ Finance 5(1):1275087. https://doi.org/10.1080/23322039.2016.12750 87

Khanal U, Wilson C, Lee BL, Hoang VN (2018) Climate change adaptation strategies and food productivity in Nepal: a counterfactual analysis. Climatic Change 148(4):575-590. https://doi. org/10.1007/s10584-018-2214-2

Kuang F, Jin J, He R, Wan X, Ning J (2019) Influence of livelihood capital on adaptation strategies: evidence from rural households in Wushen Banner. China Land Use Policy 89:104228. https://doi. org/10.1016/j.landusepol.2019.104228

Li S, Juhász-Horváth L, Harrison PA, Pintér L, Rounsevell MD (2017) Relating farmer's perceptions of climate change risk to adaptation behavior in Hungary. J Environ Manage 185:21-30. https://doi. org/10.1016/j.jenvman.2016.10.051

Li WJ, Wen JH, Wu YJ (2014) PGIS based probabilistic community flood disaster risk assessment: a case of Taining County Town. Fujian Province Geograph Res 33(1):31-42 ((in Chinese))

Lindell MK (2013) North American cities at risk: Household responses to environmental hazards. In: Joffe H, Rossetto T, Adams J (eds) Cities at risk. Springer, New York and London, pp 109-130

Lindell MK, Perry RW (2000) Household adjustment to earthquake hazard: a review of research. Environ Behav 32(4):461-501. https://doi.org/10.1177/00139160021972621

Lindell MK, Prater CS, Wu HC, Huang SK, Johnston DM, Becker JS et al (2016) Immediate behavioural responses to earthquakes in Christchurch, New Zealand, and Hitachi. Japan Disasters 40(1):85111. https://doi.org/10.1111/disa. 12133

Liu MB, Wei W, Li X (2015) Study on factors influencing the intention of preventive migration in ecologically high-risk areas: based on a survey of 4 villages in DingXi District, GanSu Province. J China Univ Geosci (Soc Sci Edit) 15(06):22-29 ((in Chinese))

Liu W, Li J, Ren L, Xu J, Li C, Li S (2020) Exploring livelihood resilience and its impact on livelihood strategy in rural China. Soc Indic Res. https://doi.org/10.1007/s11205-020-02347-2

Lo AY, Cheung LTO (2015) Seismic risk perception in the aftermath of Wenchuan earthquakes in Southwestern China. Nat Hazards 78(3):1979-1996. https://doi.org/10.1007/s11069-015-1815-6 
Knutsson P, Ostwald M (2006) A process-oriented sustainable livelihoods approach-a tool for increased understanding of vulnerability, adaptation and resilience. Mitig Adapt Strat Glob Change. https:// doi.org/10.1007/s11027-006-4421-9

Marschke MJ, Berkes F (2006) Exploring strategies that build livelihood resilience: a case from Cambodia. Ecol Soc 11(1):42. https://doi.org/10.1016/j.ecolecon.2005.06.002

Mekuyie M, Jordaan A, Melka Y (2018) Understanding resilience of pastoralists to climate change and variability in the Southern Afar Region, Ethiopia. Climate Risk Manag 20:64-77. https://doi. org/10.1016/j.crm.2018.02.004

Mentamo M, Geda NR (2016) Livelihood diversification under severe food insecurity scenario among smallholder farmers in Kadida Gamela District. Southern Ethiopia Kontakt 18(4):e258-e264. https://doi.org/10.1016/j.kontakt.2016.09.003

Milestad R, Darnhofer I (2003) Building farm resilience: the prospects and challenges of organic farming. J Sustain Agric 22(3):81-97. https://doi.org/10.1300/J064v22n03_09

Mottaleb KA, Ali A (2018) Rural livelihood diversification strategies and household welfare in Bhutan. Euro J Dev Res 30(4):718-748. https://doi.org/10.1057/s41287-017-0120-5

Nguyen KV, James H (2013) Measuring household resilience to floods: a case study in the vietnamese Mekong River Delta. Ecol Soc 18(3):13

Obrist B, Pfeiffer C, Henley R (2010) Multi-layered social resilience: a new approach in mitigation research. Prog Dev Stud 10(4):283-293. https://doi.org/10.1177/146499340901000402

Peng Y, Zhu X, Zhang F, Huang L, Xue J, Xu Y (2018) Farmers' risk perception of concentrated rural settlement development after the 5.12 Sichuan Earthquake. Habitat Int 71:169-176. https://doi. org/10.1016/j.habitatint.2017.11.008

Peng L, Tan J, Lin L, Xu DD (2019a) Understanding sustainable disaster mitigation of stakeholder engagement: risk perception, trust in public institutions, and disaster insurance. Sustain Dev 27(5):885-897. https://doi.org/10.1002/sd.1948

Peng L, Xu DD, Wang XX (2019b) Vulnerability of rural household livelihood to climate variability and adaptive strategies in landslide-threatened western mountainous regions of the three gorges reservoir area. China Climate Dev 11(6):469-484. https://doi.org/10.1080/17565529.2018.1445613

Rahman S, Akter S (2014) Determinants of livelihood choices. J South Asian Dev 9:287-308. https:// doi.org/10.1177/0973174114549101

Schramski S, Keys E (2013) Smallholder response to hurricane Dean: creating new human ecologies through charcoal production. Nat Hazards Rev 14(4):211-219. https://doi.org/10.1061/(asce) nh.1527-6996.0000100

Shah KU, Dulal HB (2015) Household capacity to adapt to climate change and implications for food security in Trinidad and Tobago. Reg Environ Change 15(7):1379-1391

Simtowe F (2015) Land redistribution impacts on livelihood diversification: the case of a market-assisted land redistribution program in Malawi. Development 58(2-3):366-384. https://doi.org/10.1057/ s41301-016-0024-2

Sina D, Chang-Richards AY, Wilkinson S, Potangaroa R (2019) A conceptual framework for measuring livelihood resilience: relocation experience from Aceh, Indonesia. World Dev 117:253-265. https ://doi.org/10.1016/j.worlddev.2019.01.003

Speranza CI, Wiesmann U, Rist S (2014) An indicator framework for assessing livelihood resilience in the context of social-ecological dynamics. Global Environ Change 28:109-119. https://doi. org/10.1016/j.gloenvcha.2014.06.005

Smith LC, Frankenberger TR (2018) Does resilience capacity reduce the negative impact of shocks on household food security? Evidence from the 2014 floods in northern Bangladesh. World Devel. https://doi.org/10.1016/j.worlddev.2017.07.003

Su, F., X, Z. M., S, H. Y. (2009). A review of sustainable livelihood analysis. Adv Earth Sci, 24(01), 61-69 (in Chinese)

Thomas TN, Sobelson RK, Wigington CJ, Davis AL, Harp VH, Leander-Griffith M, Cioffi JP (2018) Applying instructional design strategies and behavior theory to household disaster preparedness training. J Public Health Manag Practice 24(1):e16-e25

Thulstrup AW (2015) Livelihood resilience and adaptive capacity: tracing changes in household access to capital in Central Vietnam. World Dev 74:352-362. https://doi.org/10.1016/j.world dev.2015.05.019

Tian L, Yao P, Jiang SJ (2014) Perception of earthquake risk: a study of the earthquake insurance pilot area in China. Nat Hazards 74(3):1595-1611. https://doi.org/10.1007/s11069-014-1257-6

Trinh TQ, Rañola RF Jr, Camacho LD, Simelton E (2018) Determinants of farmers' adaptation to climate change in agricultural production in the central region of Vietnam. Land Use Policy 70:224231. https://doi.org/10.1016/j.landusepol.2017.10.023 
Villagra P, Rojas C, Ohno R, Xue M, Gómez K (2014) A GIS-base exploration of the relationships between open space systems and urban form for the adaptive capacity of cities after an earthquake: the cases of two Chilean cities. Appl Geogr 48:64-78. https://doi.org/10.1016/j.apgeog.2014.01.010

Walker B, Hollin CS, Carpenter SR (2004) Resilience, adaptability and transformability in social-ecological systems. Ecol Soc 9(2):5. https://doi.org/10.1890/04-0463

Wang XP (2012) Study on Family Disaster preparedness Strategies in ethnic Areas from the perspective of vulnerability Analysis. Lanzhou University, Lanzhou ((in Chinese))

Whitehead JC, Edwards B, Van Willigen M, Maiolo JR, Wilson K, Smith KT (2001) Heading for higher ground: factors affecting real and hypothetical hurricane evacuation behavior. Environ Hazards 2(4):133-142. https://doi.org/10.3763/ehaz.2000.0219

Xie RS (2019) On the Influence of Farmers' livelihood capital on the choice of livelihood strategies in rural Tourism destinations. Hunan Normal University, Changsha ((in Chinese))

Xie H (2008) Analysis of influencing factors of rural household relocation intention in new rural construction: a case study of Anfeng Town, DongTai City. JiangSu Province Small Town Constr 03:52-54 ((in Chinese))

Xu D, Zhang J, Rasul G, Liu S, Xie F, Cao M, Liu E (2015) Household livelihood strategies and dependence on agriculture in the mountainous settlements in the three gorges reservoir area. China Sustainability 7(5):4850-4869. https://doi.org/10.3390/su7054850

Xu D, Peng L, Liu S, Wang X (2018a) Influences of risk perception and sense of place on landslide disaster preparedness in southwestern China. Int J Disaster Risk Science 9(2):167-180. https://doi. org/10.1007/s13753-018-0170-0

Xu D, Liu E, Wang X, Tang H, Liu S (2018b) Rural households' livelihood capital, risk perception, and willingness to purchase earthquake disaster insurance: evidence from southwestern China. Int J Environ Res Public Health 15(7):1319. https://doi.org/10.3390/ijerph15071319

Xu D, Deng X, Guo S, Liu S (2019a) Sensitivity of livelihood strategy to livelihood capital: an empirical investigation using nationally representative survey data from rural China. Soc Indic Res 144(1):113131. https://doi.org/10.1007/s11205-018-2037-6

Xu DD, Yong ZL, Deng X, Liu Y, Huang K, Zhou WF et al (2019b) Financial preparation, disaster experience, and disaster risk perception of rural households in earthquake-stricken areas: evidence from the Wenchuan and Lushan earthquakes in China's Sichuan Province. Int J Environ Res Public Health 16(18):3345. https://doi.org/10.3390/ijerph16183345

Xu D, Deng X, Guo S, Liu S (2019c) Labor migration and farmland abandonment in rural China: empirical results and policy implications. J Environ Manage 232:738-750. https://doi.org/10.1016/j.jenvm an.2018.11.136

Xu D, Deng X, Huang K, Liu Y, Yong Z, Liu S (2019d) Relationships between labor migration and cropland abandonment in rural China from the perspective of village types. Land Use Policy 88:104164. https://doi.org/10.1016/j.landusepol.2019.104164

Xu D, Zhou W, Deng X, Ma Z, Yong Z, Qin C (2020a) Information credibility, disaster risk perception and evacuation willingness of rural households in China. Nat Hazards. https://doi.org/10.1007/s1106 9-020-04106-5

Xu D, Qing C, Deng X, Yong Z, Zhou W, Ma Z (2020b) Disaster risk perception, sense of pace, evacuation willingness, and relocation willingness of rural households in earthquake-stricken areas: evidence from Sichuan Province, China. Int J Environ Res Public Health 17(2):602. https://doi.org/10.3390/ ijerph17020602

Xu D, Zhuang L, Deng X, Qing C, Yong Z (2020c) Media exposure, disaster experience, and risk perception of rural households in earthquake-stricken areas: evidence from rural China. Int J Environ Res Public health 17(9):3246. https://doi.org/10.3390/ijerph17093246

Yan JZ, Yu O, WU YY (2011) Livelihood vulnerability assessment of farmers and herdsmen in the eastern Tibetan Plateau. Geography 7:858-867. https://doi.org/10.1631/jzus.B1000152

Zeng XY, Guo SL, Deng X, Zhou WF, Xu DD (2020) Livelihood risk and adaptation strategies of farmers in earthquake hazard threatened areas: evidence from Sichuan province, China. Int J Disaster Risk Reduct. https://doi.org/10.1016/j.ijdrr.2020.101971

Zhou H, Wan J, Jia H (2010) Resilience to natural hazards: a geographic perspective. Nat Hazards 531:2141. https://doi.org/10.1007/s11069-009-9407-y

Zhuang L, He J, Yong Z, Deng X, Xu D (2020) Disaster information acquisition by residents of China's earthquake-stricken areas. Int J Disaster Risk Reduct 51:101908. https://doi.org/10.1016/j.ijdrr .2020 .101908

Publisher's Note Springer Nature remains neutral with regard to jurisdictional claims in published maps and institutional affiliations. 


\section{Affiliations}

\section{Wenfeng Zhou ${ }^{1} \cdot$ Shili Guo ${ }^{2} \cdot$ Xin Deng $^{3} \cdot$ Dingde Xu ${ }^{1,4}$}

1 College of Management of Sichuan Agricultural University, Chengdu 611130, China

2 China Western Economic Research Center, Southwestern University of Finance and Economics, Chengdu 610074, China

3 College of Economics of Sichuan Agricultural University, Chengdu 611130, China

4 Sichuan Center for Rural Development Research, College of Management of Sichuan Agricultural University, Chengdu 611130, China 